\title{
STRATEGI PENGEMBANGAN KURIKULUM 2013 PENDIDIKAN AGAMA ISLAM BERBASIS MULTIKULTURAL
}

\author{
Triana Rosalina Noor \& Khoirun Nisa'il Fitriyah \\ STAI An-Najah Indonesia Mandiri ; STAI Sabilul Muttaqin \\ trianasuprayoga@gmail.com ; nisakstaisam@gmail.com
}

\begin{abstract}
Conflicts with ethnic and religious nuances is partly due to the lack of insight into the understanding of cultural diversity. Responding to this situation, Islamic Religious Education is important to develop the multicultural perspective so that the reality of a multicultural society can be accommodated in it. This study used a qualitative approach with the type of case study, with the research location at SMA Kertajaya Surabaya. The informants of this study were the principal and Islamic education teachers, using the method of collecting data through interviews, observation and documentation study. The data that has been obtained are analyzed, interpreted and interpreted qualitatively descriptive. The findings obtained that the formulation of the PAI curriculum that applied was flexible and based on an analysis of the situation faced by the community. The PAI design that is applied considers the multicultural aspects that exist in society by paying attention to the situation of students, and the teachers who carry out learning activities. The strategy used is to include multicultural values such as a sense of justice, love and compassion, mutual respect between teachers and students, between school institutions and elements to the society.
\end{abstract}

Keywords: Curriculum Development, Curriculum 2013, PAI Multicultural Based

\begin{abstract}
Abstrak : Bermunculannya konflik yang bernuansa etnis dan agama salah satunya disebabkan minimnya wawasan pemahaman atas keragaman budaya yang seharusnya menjadi sebuah keniscayaan. Merespon hal tersebut Pendidikan Agama Islam penting untuk dikembangkan dalam wawasan multikultural agar realitas masyarakat multikultural bisa diakomodasi didalamnya. Penelitian ini menggunakan pendekatan kualitatif dengan jenis studi kasus, dengan lokasi penelitian di SMA Kertajaya Surabaya. Informan penelitian ini adalah kepala sekolah dan guru PAI, dengan metode pengambilan data melalui wawancara, observasi dan studi dokumentasi. Data yang telah didapatkan dianalisis, dimaknai dan diinterpretasikan secara kualititatif deskriptif. Hasil temuan yang didapatkan adalah perumusan kurikulum PAI yang diterapkan bersifat fleksibel dan berdasarkan pada analisis situasi yang dihadapi masyarakat. Desain PAI yang diterapkan mempertimbangkan aspek multikultural yang ada di masyarakat dengan memperhatikan situasi siswa, dan para pengajar yang melaksanakan kegiatan pembelajaran. Strategi yang digunakan adalah memasukkan nilai-nilai multikultural seperti rasa keadilan, kasih, dan sayang, saling menghargai baik antara para guru dan siswa, antara institusi sekolah dan para unsur didalam sekolah serta dengan masyarakat.
\end{abstract}

Kata Kunci : Pengembangan Kurikulum, Kurikulum 2013, PAI Berbasis Multikultural 


\section{PENDAHULUAN}

Pendidikan merupakan salah satu elemen penting untuk dapat memajukan kehidupan bangsa dan negara. Peran pendidikan tidak bisa diabaikan begitu saja untuk mewarnai pekembangan peradaban umat manusia. Munculnya pendidikan multikultiral adalah sebagai bentuk membangun suatu pendidikan yang bebas prasangka sosial dan kultural dan semua orang membutuhkan itu. ${ }^{1}$

Pembahasan mengenai pendidikan maka tidak bisa lepas dari membahas tentang kurikulum. Kurikulum adalah alat untuk mencapai tujuan, sekaligus sebagai pedoman dalam pelaksanaan pendidikan. Kurikulum mencerminkan falsafah hidup bangsa, arah dan tujuan kehidupan suatu bangsa. Kehidupan suatu bangsa di mana pun dan kapan pun selalu mengalami perkembangan, baik segi sosial, politik maupun ekonominya. Nilai sosial, kebutuhan dan tuntutan masyarakat cenderung mengalami perubahan yang disebabkan oleh kamajuan ilmu pengetahuan dan teknologi. Untuk mengantisipasi perubahan itu, pendidikan diharapkan mampu menjadi solusi, sebab selama ini pendidikan masih dianggap sebagai salah satu cara yang paling strategis untuk mengimbangi kemajuan ilmu pengetahuan dan teknologi. ${ }^{2}$ Kurikulum merupakan suatu alat yang digunakan untuk mencapai tujuan pendidikan sehingga membawa manfaat untuk masing-masing individu dan lingkungannya. ${ }^{3}$ Kurikulum akan menjadi panduan dalam pelaksanaan pembelajaran pada semua jenis dan jenjang pendidikan.

Sebuah kurikulum haruslah bersifat dinamis, artinya akan menyesuaikan perubahan dan perkembangan zaman, ilmu pengetahuan dan kebutuhan masyarakat. Pada pelaksanaannya pun, sebuah kurikulum harus tetap dimonitoring dan di evaluasi agar dalam pengembangannya selalu bisa diperbaiki dan disempurnakan sesuai kebutuhan. ${ }^{4}$

\footnotetext{
${ }^{1}$ Zakiyuddin Baidhawy, Pendidikan Agama Berwawasan Multikultural (Jakarta: Erlangga, 2007), 9.

${ }^{2}$ Ahmad Wahyu Hidayat, "Studi Kebijakan Pengembangan Kurikulum Pendidikan Agama Islam Model Kurikulum 2013," AL-MURABBI: Jurnal Studi Kependidikan dan Keislaman 6, no. 2 (2020): 173174.

3 Triana Rosalina Noor, "Pendidikan Islam Sebagai Sebuah Sistem Di Era 4.0," TA'LIM: Jurnal Studi Pendidikan Islam 2, no. 2 (2019): 21.

${ }^{4}$ Zainal Arifin, Konsep Dan Model Pengembangan Kurikulum (Bandung: PT. Remaja Rosdakarya, 2012), 2.
} 
Kurikulum sebagai sebuah rencana tertulis yang berisikan tentang rumusan tujuan, bahan ajar, kegiatan belajar mengajar sampai pada proses evaluasi pembelajaran, sebagaimana penerapan fungsi manajemen. ${ }^{5}$ Pada praktiknya, kurikulum di Indonesia telah beberapa kali mengalami pergantian sebagai bentuk keinginan untuk memperbaiki ketidakpuasan ata hasil pendidikan kurikulum sebelumnya. Saat Kurikulum Tingkat Satuan Pendidikan (KTSP) dihentikan maka ditetapkannya Kurikulum 2013 menjadi pengganti sebagai bentuk usaha untuk memperbaiki proses pembelajaran yang sudah berjalan sebelumnya. Orientasi kurikulum 2013 adalah untuk mencapai kompetensi yang berimbang antara sikap, keterampilan dan pengetahuan dengan metode pembelajaran yang holistik dan menyenangkan. ${ }^{6}$

Melalui implementasi kurikulum 2013 diharapkan akan semakin terbentuk sikap siswa yang santun dan baik. Harapan terbentuknnya sikap siswa yang berakhlak mulia adalah salah satunya diberikan melalui pendidikan di sekolah salah satunya Pendidikan Agama Islam (PAI). Melalui mata pelajaran PAI diharapkan bisa sebagai sumber nilai dan pedoman bagi siswa dalam mencapai kebahagaiaan hidup di dunia dan akhirat. PAI menjadi inspirasi siswa dalam berpikir dan berbuat sehingga seluruh aktivitas di kehidupannya akan berdasarkan pada norma dan nilai agama dalam berbagai hal. $^{7}$

Secara horizontal, Bangsa Indonesia dianugerahi oleh masyarakat yang multikultural dengan ragam dan ciri khas masing-masing, baik itu dari budaya, agama, bahasa dan sebagainya. Secara vertikal. Masyarakat Indonesia memiliki keragaman lapisan-lapisan dalam masyarakat berdasarkan ekonomi, pendidikan, status sosial, pekerjaan dan sebagainya. Perbedaan-perbedaan ini berpotensi membawa masyarakat kepada konflik-konflik yang mengarah pada tindakan destruktif seperti kekerasan atau kerusuhan massa. ${ }^{8}$ Bahayanya adalah perbedaan-perbedaan yang seharusnya

\footnotetext{
5 Triana Rosalina Noor, "Manajemen Pendidikan Anak Melalui Program Outbound Di TK Al Muslim Surabaya," SELING: Jurnal Program Studi PGRA 3, no. 2 (2017): 173.

${ }^{6}$ Loeloek Endah Poerwati and Sofan Amri, Panduan Memabami Kurikulum 2013: Sebuah Inovasi Struktur Kurikulum Penunjang Pendidikan Masa Depan (Jakarta: PT. Prestasi Pustakaraya, 2013), 6.

7 Suparta Suparta, Pengantar Teori Dan Aplikasi Pengembangan Kurikulum PAI (Jakarta: PT. RajaGrafindo Persada, 2016), 11.

8 Triana Rosalina Noor, "Alternatif Pemecahan Masalah Pada Masyarakat Multikultural," Al Iman: Jurnal Keislaman dan Kemasyarakatan 4, no. 2 (2020): 230.
} 
dihargai dan dijaga, oleh oknun-oknum tertentu justru dijadikan sumber pemicu konflik dengan mengatasnamakan agama. ${ }^{9}$ Hal tersebut mengakibatkan munculnya prasangka, diskriminasi dan ketidakpercayaan antara pemeluk agama yang satu dengan yang lain. ${ }^{10}$ Mengacu pada kondisi ini, alternatif yang bisa diambil dalam konteks pendidikan adalah melalui pendidikan agama yang dikelola dengan semangat multikultural.

Adapun konsep dari PAI berbasis multikultural adalah sebuah konsep pendidikan yang dikelola dengan semangat multikultural, bukan dengan semangat doktial keagamaan yang membawa pada suatu penanaman kebencian atas pemeluk agama yang lain. PAI berbasis multikultural menawarkan sebuah pembelajaran yang mengajak pembelajar untuk bersikap toleran terhadap orang lain, inklusif, tidak egois, berpikir terbuka dan menjadi pribadi yang baik di masyarakat. ${ }^{11}$ Artinya melalui PAI yang berbasis multikultural diharapkan bisa menjadi penguat bagi karakter siswa dalam berinteraksi sosial dalam lingkungan yang heterogen. PAI yang diberikan merupakan pendiidkan yang terintegrasi dengan nilai-nilai hidup di masyarakat nyata ${ }^{12}$ dan juga merupakkan pengembangan nila-nilai keagamaan yangdidapatkan pada fase perkembangan sebelumnya. ${ }^{13}$

SMA Kertajaya adalah salah satu sekolah swasta di kota Surabaya, yang memiliki siswa beragam asal daerahnya. Siswa tidak hanya berasal dari daerah Surabaya, namun peserta didik tersebut berasal dari beberapa daerah di luar Surabaya bahkan luar Jawa, seperti Nusa Tenggara. Selain itu perbedaan sosial ekonomi juga terlihat di sana, antara keluarga yang berasal dari kalangan yayasan panti asuhan, kalangan bawah, menengah, dengan pekerjaan orang tuanya mulai dari PNS,

\footnotetext{
9 Triana Rosalina Noor, "Meneropong Indonesia: Sebuah Analisis Sosiologis Dan Psikologis Atas Konflik Benuansa Keagamaan Di Indonesia," Journal An-Nafs: Kajian Penelitian Psikologi 3, no. 2 (2018): 148.

10 Triana Rosalina Noor, "Menepis Prasangka Dan Diskriminasi Dalam Perilaku Beragama Untuk Masa Depan Multikulturalisme Di Indonesia," Fikri: Jurnal Kajian Agama, Sosial dan Budaya 5, no. 2 (2020): 220 .

11 Kasinyo Harto, Model Pengembangan Pendidikan Agama Islam Berbasis Multikultural (Jakarta: PT. RajaGrafindo Persada, 2014), 69.

12 Triana Rosalina Noor, "Remaja Dan Pemahaman Agama," Vicratina: Jurnal Pendidikan Islam 3, no. 2 (2019): 68.

13 Triana Rosalina Noor, "MENGEMBANGKAN JIWA KEAGAMAAN ANAK (Perspektif Pendidikan Islam Dan Perkembangan Anak Usia Dini)," KUTTAB 4, no. 2 (2020): 467.
} 
wiraswasta sampai tenaga serabutan. Sistem pembiayaan dari peserta didik ada yang bersifat mandiri dan beasiswa. ${ }^{14}$

SMA Kertajaya Surabaya bernaung di bawah Yayasan Baiturahman yang juga mengelola beberapa lembaga pendidikan Islam. Namun sekolah ini terbuka bagi siswa non muslin yang ingin bersekolah di sana. Tiap tahun setidaknya ada satu peserta didik yang non-muslim meskipun secara keseluruhan jumlahnya sangat sedikit. Selain itu, oleh karena dibawah naungan Yayasan Baiturrahman yaitu yayasan keislaman sehingga peserta didik yang ada di sekolah tersebut ada yang berasal dari latar belakang organisasi Islam Nahdlatul Ulama' (NU) dan Muhammadiyah, yang mana kedua organisasi tersebut mempunyai perbedaan dalam tata cara beribadah. ${ }^{15}$ Sampai dengan tahun ajaran 2019-2020 ini, jumlah peserta didik di SMA Kertajaya sebanyak 100 orang dengan jumlah 58 orang peserta didik laki-laki dan 42 orang perempuan yang tersebar pada kelas X, XI dan XII, denga masing-masing memiliki dua kelas pada tiap jenjangnya. ${ }^{16}$

Proses pembelajaran di SMA Kertajaya Surabaya menggunakan kurikulum 2013 sebagaimana ketentuan pemerintah, dan mulai diimplementasikan sejak tahun 2017. Salah satu pelajaran yang menerapkan kurikulum 2013 adalah pembelajaran Pendidikan Agama Islam yang dalam pelaksanaannya dikaitkan dengan isu-isu berwawasan multikultural. Hal ini terlihat pada pemahaman guru Agama Islam maupun dari berbagai materi yang diajarkan yang kemudian diintegrasikan dengan perilaku-perilaku multikultural di lingkungan sekolah. Penegasan dari Kepala Sekolah dari SMA Kertajaya yang sekaligus menjadi guru PAI di sekolah tersebut, bahwa di sekolah tersebut terdapat siswa yang memiliki agama Kristen dan juga memiliki perbedaan latar belakang. ${ }^{17}$

Melalui PAI berbasis multikultural diharapkan siswa bisa memahami agama dengan lebih terbuka Harapannya adalah dengan perbedaan yang ada, siswa tersebut agar dapat hidup bersama secara damai dan saling menghargai walaupun dengan latar

\footnotetext{
${ }^{14}$ Ibu Samini (Kepala SMA Kertajaya Surabaya), wawancara, 16 Maret 2020

${ }^{15}$ Ibu Samini (Kepala SMA Kertajaya Surabaya), wawancara, 16 Maret 2020

${ }^{16}$ Data dokumentasi SMA Kertajaya Surabaya

${ }^{17}$ Ibu Samini (Kepala SMA Kertajaya Surabaya), wawancara, 16 Maret 2020
} 
belakang yang berbeda-beda, bukan hanya di kehidupan sekolah tapi juga saat bermasyarakat.

\section{METODE PENELITIAN}

Penelitian ini dilakukan di SMA Kertajaya yang terletak di Jl. Juwingan No. 1 B, Surabaya. Penelitian ini menggunakan pendekatan kualitatif dengan jenis studi kasus, yakni sebuah penelitian yang bertujuan untuk mencari, memaknai dan mencari pemahaman untuk selanjutnya mengambil kesimpulan atas data tersebut. ${ }^{18}$ Pemilihan informan penelitian dilakukan dengan menggunakan teknik purposive sampling, yakni pihak yang telah ditentukan sebelumnya oleh karena kelebihtahuannya atas kondisi lokasi penelitian. Informan penelitian ini adalah kepala sekolah yang sekaligus guru PAI di SMA Kertajaya Surabaya.

Teknik pengumpulan data yang digunakan peneliti terdiri dari tiga teknik yaitu wawancara mendalam (Indepth Interview), observasi partisipan (Partisicipant Observation) dan studi dokumen. ${ }^{19}$ Data yang telah didapatkan selanjutnya dianalisis secara tunggal secara deskriptif.

\section{HASIL DAN PEMBAHASAN}

\section{Landasan Kurikulum di SMA Kertajaya Surabaya}

Penerapan kurikulum 2013 di SMA Kertajaya Surabaya mengacu pada beberapa landasan yang selaras dengan tujuan pendidikan nasional yaitu :

1. Landasan Filosofis.

Kurikulum pada hakekatnya berfungsi untuk mempersiapkan anggota masyarakat yang dapat mempertahankan, mengembangkan, dan hidup dalam sistem nilai masyarakatnya. Sistem nilai yang berlaku di Indonesia adalah Pancasila dan berakar pada budaya bangsa, diharapkan memmbentuk manusia yang Pancasilais dan sebagai pewaris budaya bangsa yang peduli terhadap

\footnotetext{
${ }^{18}$ M. Djunadi Ghony and Fauzan Almanshur, Metodologi Penelitian Kualitatif (Yogyakarta: Ar-Ruzz Media, 2017), 62.

19 Sugiyono Sugiyono, Metode Penelitan Pendidikan: Pendekatan Kuantitatif, Kualitatif Dan R\&D (Bandung: CV. Alfabeta, 2016). 309
} 
permasalahan masyarakat dan bangsa merupakan tujuan dan arah dari segala ikhtiar berbagai jalur, jenjang, dan jenis pendidikan. ${ }^{20}$ Dengan demikian kurikulum 2013 menggunakan filosofi sebagaimana diatas dalam mengembangkan kehidupan individu peserta didik dalam beragama, seni kreativitas, berkomunikasi, nilai dan berbagai dimensi intelegensi yang sesuai dengan diri seorang peserta didik dan diperlukan masyarakat bangsa dan umat manusia.

2. Landasan Psikologis

Dalam proses pendidikan terjadi interaksi antar individu manusia yaitu antar peserta didik dengan pendidik, antara peserta didik dengan peserta didik yang lain. Kondisi psikologis setiap individu berbeda, karena berbeda taraf perkembangan, latar belakangnya juga karena perbedaan yang dibawa sejak lahir. Minimal ada dua bidang psikologi yang mendasari pengembangan kurikulum, yaitu psikologi perkembangan dan psikologi belajar, keduanya sangat diperlukan baik dalam merumuskan tujuan, memilih dan menyusun bahan ajar, memilih dan menerapkan metode pembelajaran serta teknik-teknik penilaian. ${ }^{21}$

Kurikulum 2013 dimaksudkan sebagai wahana pendewasaan peserta didik sesuai dengan perkembangann psikologisnya dan mendapatkan perlakuan pedagogis sesuai dengan konteks lingkungan dan jamannya.

3. Landasan Sosiologis

Kurikulum dapat dipandang sebagai suatu rancangan pendidikan, kita ketahui bahwa pendidikan mempersiapkan generasi muda untuk terjun ke lingkungan masyarakat. Pendidikan bukan hanya untuk pendidikan, tetapi memberikan bekal pengetahuan, ketrampilan serta nilai-nilai untuk hidup, bekerja dan mencapai perkembangan lebih lanjut di masyarakat. Anak-anak berasal dari masyarakat, mendapatkan pendidikan baik formal maupun informal dalam lingkungan masyarakat dan diarahkan bagi kehidudpan dalam masyarakat

\footnotetext{
${ }^{20}$ Herry Widyastono, Pengembangan Kurikulum Di Era Otonomi Daerah Dari Kurikulum 2004, 2006 Ke Kurikulum 2013 (Jakarta: CV. Bumi Aksara, 2015), 25.

${ }^{21}$ Heri Gunawan, Kurikulum Dan Pembelajaran Pendidikan Agama Islam (Bandung: CV. Alfabeta, 2012), 38 .
} 
juga.kehidupan masyarakat dengan segala karakteristik dan kekayaan budayanya menjadi landasan dan acuan bagi pendidikan. ${ }^{22}$

Kurikulum 2013 dikembangkan atas dasar adanya tuntutan akan perubahan rancangan dan proses pendidikan dalam rangka memenuhi dinamika kehidupan masyarakat, bangsa, dan negara. Perubahan ini dimungkinkan karena berkembangnya tuntutan baru dalamm masyarakat, dunia kerja dan dunia ilmu pengetahuan.

4. Landasan Yuridis

Landasan yuridis kurikulum 2013 adalah:

a. Undang-Undang Dasar Negara Republik Indonesia Tahun 1945.

b. Undang-Undang No 20 tahun 2003 tentang Sistem Pendidikan Nasional.

c. Undang-Undang No 17 Tahun 2005 tentang Rencana Pembangunan Jangka panjang Nasional, beserta segala ketentuan yang dituangkan Rencana Pembangunan Jangka Menengah Nasional.

d. Peraturan pemerintah No 19 tahun 2015 tentang Standar Nasional Pendidikan sebagaimana telah diubah dengan Peraturan Pemerintah No 32 Tahun 2013 tentang perubahan atas Peraturan Pememrintah No 19 tahun 2005 tentang Standar Nasional pendidikan.

e. Permendikbud Nomor 37 Tahun 2018 Tentang KI dan KD K13 SD, SMP \& SMA

5. Landasan Teoritis

Kurikulum 2013 dikembangkan atas teori pendidikan berdasarkan standar ( standart based education) dan teori kurkulum berbasis kompetensi (competence-based curriculum). Pendidikan berdasarkan standar sebagai kualitas minimal warganegara yang dirinci menjadi Standar Isi, Standar Proses, Standar Kompetensi Lulusan, Standar Sarana dan Prasarana, Standar Pengelolaan, Standar Pembiayaan dan Standar Penilaian pendidikan. kurikulum berbasis kompetensi dirancang untuk memberikan pengalaman belajar seluas-luasnya bagi peserta didik dalam

22 Ibid., 39. 
mengembangkan kemampuan untuk bersikap, berpengalaman, berketrampilan dan bertindak.

Kurikulum 2013 menganut; (1) pembelajaran yang dilakukan guru (taught curriculum) dalam bentuk proses yang dikembangkan berupa kegiatan pembelajaran di sekolah, kelas dan masyarakat; dan (2) pengalaman belajar langsung peserta didik (learned-curriculum) sesuai dengan latar belakang, karakteristik, dan kemampuan awal peserta didik. Pengalaman belajar langsung individual peserta didik menjadi hasil belajar bagi dirinya, sedangkan hasil belajar seluruh peserta didik menjadi hasil kurikulum. ${ }^{23}$

\section{Strategi dan Model Penyusunan dan Pengembangan Kurikulum 2013 PAI Multikultural di SMA Kertajaya Surabaya}

Sebelum kurikulum 2013 diterapkan di SMA Kertajaya Surabaya, sekolah masih menggunakan KTSP (Kurikulum Tingkat Satuan Pendidikan). Kurikulum 2013 mulai diterapkan di SMA Kertajaya Surabaya yaitu mulai tahun ajaran 2017-2018. Pengembangan kurikulum 2013 yang diterapkan merupakan lanjutan Pengembangan Kurikulum Berbasis Kompetensi (KBK) yang telah dirintis pada tahun 2004 dan KTSP 2006 yang mencakup kompetensi sikap, pengetahuan, dan keterampilan secara terpadu, tidak terkecuali pada mata pelajaran Pendidikan Agama Islam (PAI). Terkait strategi penyusunan Kurikulum 2013 PAI berbasis multikultural yang diterapkan oleh SMA Kertajaya adala sebagai berikut : ${ }^{24}$

1. Pengembangan kurikulum tingkat nasional

Secara top down pengembangan kurikulum 2013 PAI di SMA Kertajaya Surabaya menyesuaikan dengan tingkatan pendidikan yakni SMA/MA/SMK yang telah ditetapkan oleh pemerintah.

2. Pengembangan kurikulum PAI tingkat sekolah

\footnotetext{
23 Widyastono, Pengembangan Kurikulum Di Era Otonomi Daerah Dari Kurikulum 2004, 2006 Ke Kurikulum 2013, 135.

${ }^{24}$ Ibu Samini (Kepala SMA Kertajaya Surabaya), wawancara, 16 Maret 2020
} 
Adapun yang dimaksud pengembangan kurikulum PAI tingkat sekolah, yaitu :

a. Merumuskan tujuan

Tujuan yang dimaksud ini adalah kurikulum yang diterapkan harus sesuai visi dan misi sekolah yakni menjadi sekolah yang bermutu, mandiri dan berakhlak mulia. Misi nya adalah 1) Menyelenggarakan proses pendidikan yang berbasis life skill, 2) Menyelenggarakan pendidikan yang Islami dalam setiap proses pembelajaran dan 3) Membentuk karakter siswa yang berkepribadian Islami.

Pada konteks pembelajaran PAI, sisi multikultural yang ingin dicapai sebagaimana tujuan sekolah adalah peserta didik yang berakhlak mulia yakni peserta didik mengerti, menerima dan menghargai orang lain yang berbeda suku, budaya, dan nilai kepribadian. Pada saat perumusan kurikulum, pihak sekolah membetuk tim internal pengembang kurikulum, yang didalamnya melibatkan guru dan komite sekolah.

b. Merumuskan standar kompetensi lulusan

Standar Kompetensi Lulusan (SKL) ditetapkan untuk satu satuan pendidikan, jenjang pendidikan, program pendidikan. Penetapan SKL mengacu pada Permendikbud RI Nomor 54 Tahun 2013 tentang Standar Kompetensi Lulusan Pendidikan Dasar dan Menengah elemen-elemen. Adapun standar kompetensi lulusan meliputi tiga kompetensi, yaitu $:^{25}$

1) Kompetensi sikap, yaitu memiliki perilaku yang mencerminkan sikap orang beriman, berakhlak mulia, berilmu, percaya diri, dan bertanggung jawab dalam berinteraksi secara efektif dengan lingkungan sosial dan alam serta dalam menempatkan diri sebagai cerminan bangsa dalam pergaulan dunia.

2) Kompetensi pengetahuan, yaitu memiliki pengetahuan faktual, konseptual, prosedural, dan metakognitif dalam ilmu pengetahuan,

25 http:/ / repositori.kemdikbud.go.id/4265/1/01-a-salinan-permendikbud-no-54-tahun-2013-ttgskl.pdf. 
teknologi, seni, dan budaya dengan wawasan kemanusiaan, kebangsaan, kenegaraan, dan peradaban terkait penyebab serta dampak fenomena dan kejadian.

3) Kompetensi keterampilan, yaitu memiliki kemampuan pikir dan tindak yang efektif dan kreatif dalam ranah abstrak dan konkret sebagai pengembangan dari yang dipelajari di sekolah secara mandiri.

Dari ketiga kompetensi tersebut, kompetensi sikap yang ingin diarahkan dan dikembangkan oleh pihak sekolah pada konten PAI muktikultural, seperti sikap toleran, adil sikap menghargai sesama dan lainlain. $^{26}$

c. Merumuskan dan menetapkan isi dan struktur kurikulum

Isi atau konten kurikulum berisi kompetensi yang dinyatakan dalam bentuk kompetensi inti (KI) mata pelajaran dan dirinci lebih lanjut kedalam kompetensi dasar (KD). Adapun kompetensi Inti PAI SMA meliputi : ${ }^{27}$

KI 1 (sikap spiritual):

Menerima, menjalankan dan mengahargai ajaran agama yang dianutnya.

KI 2 (sikap sosial) :

Menunjukkan perilaku jujur, disiplin, bertanggung jawab, peduli (gotong royong, kerja sama, toleran, damai), santun, responsif, dan proaktif sebagai bagian dari solusi atas berbagai permasalahan dalam berinteraksi secara efektif dengan lingkungan sosial dan alam serta menempatkan diri sebagai cerminan bangsa dalam pergaulan dunia

KI 3 (pengetahuan):

Memahami, menerapkan, dan menganalisis pengetahuan faktual, konseptual, prosedural, dan metakognitif berdasarkan rasa ingin tahunya tentang ilmu pengetahuan, teknologi, seni, budaya, dan humaniora dengan wawasan kemanusiaan, kebangsaan, kenegaraan, dan peradaban terkait penyebab

${ }^{26}$ Ibu Samini (Kepala SMA Kertajaya Surabaya), wawancara, 17 Maret 2020

${ }^{27}$ Data dokumentasi SMA Kertajaya Surabaya 
fenomena dan kejadian, serta menerapkan pengetahuan prosedural pada bidang kajian yang spesifik sesuai dengan bakat dan minatnya untuk memecahkan masalah

KI 4 (keterampilan):

Mengolah, menalar, dan menyaji dalam ranah konkrit dan ranah abstrak terkait dengan pengembangan dari yang dipelajarinya di sekolah secara mandiri, dan mampu menggunakan metoda sesuai kaidah keilmuan.

Adapun kompetensi dasar akan menyesuaikan pada masing-masing tingkatan kelas.

c. Pengembangan SDM melalui pelatihan/ diklat/ kegiatan sejenis

SMA Kertajaya kerap mengirimkan guru-gurunya dalam kegiatan seminar ataupun pelatihan terkait kurikulum. Harapannya adalah bisa memperkaya keilmuan, khsusnya pengembangan kurikulum PAI yang berorientasi multikultural, seperti kegiatan yang sering diadakan oleh forum MGMP (Musyawarah Guru Mata Pelajaran). Forum MGMP sangat membantu dalam proses pengembangan kurikulum di SMA Kertajaya Surabaya, karena pada forum tersebut ada diskusi, masukan dari guru sekolah lain terkait teknis pembelajaran dan penilaian siswa.

3. Pengembangan kurikulum PAI tingkat mata pelajaran

Pengembangan pada aspek ini dikembangkan melalui penyiapan silabus dan Rencana Pelaksanaan Pembelajaran (RPP), yang didalamnya meliputi paparan kompetensi inti, kompetensi dasar, indikator keberhasilan rencana pembelajaran, pelaksanaan dan evaluasi pembelajaran.

Pengembangan RPP berdasarkan prinsip-prinsip tertentu, antara lain ilmiah, relevan, sistematis, konsisten, memadai, aktual dan konstektual, fleksibel, dan menyeluruh. Terkait metode pembelajaran diarahkan untuk scientific approach meski masih harus bertahap terkait kapasitas SDM. Melalui metode tersebut, guru akan juga menjelaskan konsep multikultural pada saat pembelajaran dikaitkan dengan materi yang diajarkan. 
Penerapan kurikulum 2013 tersebut secara keseluruhan, setiap tahunnya akan dievaluasi dalam forum rapat internal SMA Kertajaya, meskipun sistem evaluasi yang dilakukan di SMA Kertajaya masih sebatas evaluasi produk atau hasil. Artinya menilai keberhasilan kurikulum hanya dari aspek produk atau hasil yang dicapai oleh peserta didik seperti nilai tes. Untuk evaluasi konteks dan evaluasi proses dilakukan dalam koordinasi internal dan rapat koordinasi besar yang melibatkan guru, jajaran struktural, perwakilan komite dan unsur yayasan untuk mengetahui seberapa tingkat ketercapaiannya dan ketuntasannya pembelajaran selama satu tahun.

Terkait pengembangan Kurikulum 2013 PAI berbasis multikultural yang diterapkan oleh SMA Kertajaya adalah sebagai berikut $:^{28}$

1. Pengembangan dalam proses pembelajaran

a. Guru mengucapkan salam dan doa yang bukan hanya ditujukan kepada peserta didik yang beragama Islam, namun juga jika terdapat peserta didik non muslim di dalamnya.

b. Guru mencoba menuangkan pengalaman, contoh, studi kasus keseharian dalam tema pembelajaran PAI yang berkaitan dengan keragaman masyarakat. Berikut beberapa muatan multikultural pada pembelajaran PAI di SMA Kertajaya Surabaya, yakni:

Tabel 1 : Muatan PAI berbasis multikultural di SMA Kertajaya Surabaya

\begin{tabular}{|c|l|l|c|}
\hline No & Nilai Multikultural & \multicolumn{1}{|c|}{ Materi Pokok } & Kelas \\
\hline 1 & Persaudaraan & $\begin{array}{l}\text { Q.S. Al-Hujurat :10 dan 12, hadis } \\
\text { terkait perilaku dalam } \\
\text { bermasyarakat (kontrol diri, } \\
\text { prasangka baik dan persaudaraan) }\end{array}$ & X \\
\hline 2 & Toleransi & $\begin{array}{l}\text { Q.S. Yunus : 40-41 dan Q.S. al- } \\
\text { Maidah: 32, serta Hadis tentang } \\
\text { toleransi, rukun, dan } \\
\text { menghindarkan diri dari tindak } \\
\text { kekerasan } \\
\text { Menceritakan tentang teladan Nabi } \\
\text { Muhammad SAW saat tinggal di }\end{array}$ & \\
\hline
\end{tabular}

${ }^{28}$ Ibu Samini (Kepala SMA Kertajaya Surabaya), wawancara, 17 Maret 2020 


\begin{tabular}{|c|l|l|c|}
\hline No & Nilai Multikultural & \multicolumn{1}{|c|}{ Materi Pokok } & Kelas \\
\hline 3. & Demokratis & $\begin{array}{l}\text { Q.S. Ali Imran : 190-191, dan Q.S. } \\
\text { Ali Imran: 159, serta Hadis tentang } \\
\text { berpikir kritis dan bersikap } \\
\text { demokratis }\end{array}$ & XII \\
\hline
\end{tabular}

c. Pembelajaran di kelas secara umum menggunakan Bahasa Indonesia sebagai wujud persamaan dan keadilan bagi siswa yang berasal dari luar Jawa Timur

d. Guru bersikap adil kepada semua peserta didik dalam proses pembelajaran di kelas, seperti memberi kesempatan yang seluas-luasnya dalam berdiskusi, bertanya dan memberikan penilaian yang obyektif.

2. Pengembangan diluar proses pembelajaran

a. Memberikan kesempatan semua peserta didik untuk mengikuti kegiatan kestra kurikuler tanpa terkecuali

b. Oleh karena ada pembiasaan sholat dhuha dan sholat wajib maka secara bergiliran peserta didik laki-laki diberi tugas untuk menjadi imam.

c. Mengadakan kegiatan-kegiatan sosial yang bersifat terencana ataupun insidentil. Seperti : bhakti sosial, penggalangan dana musibah bencana alam dll. 


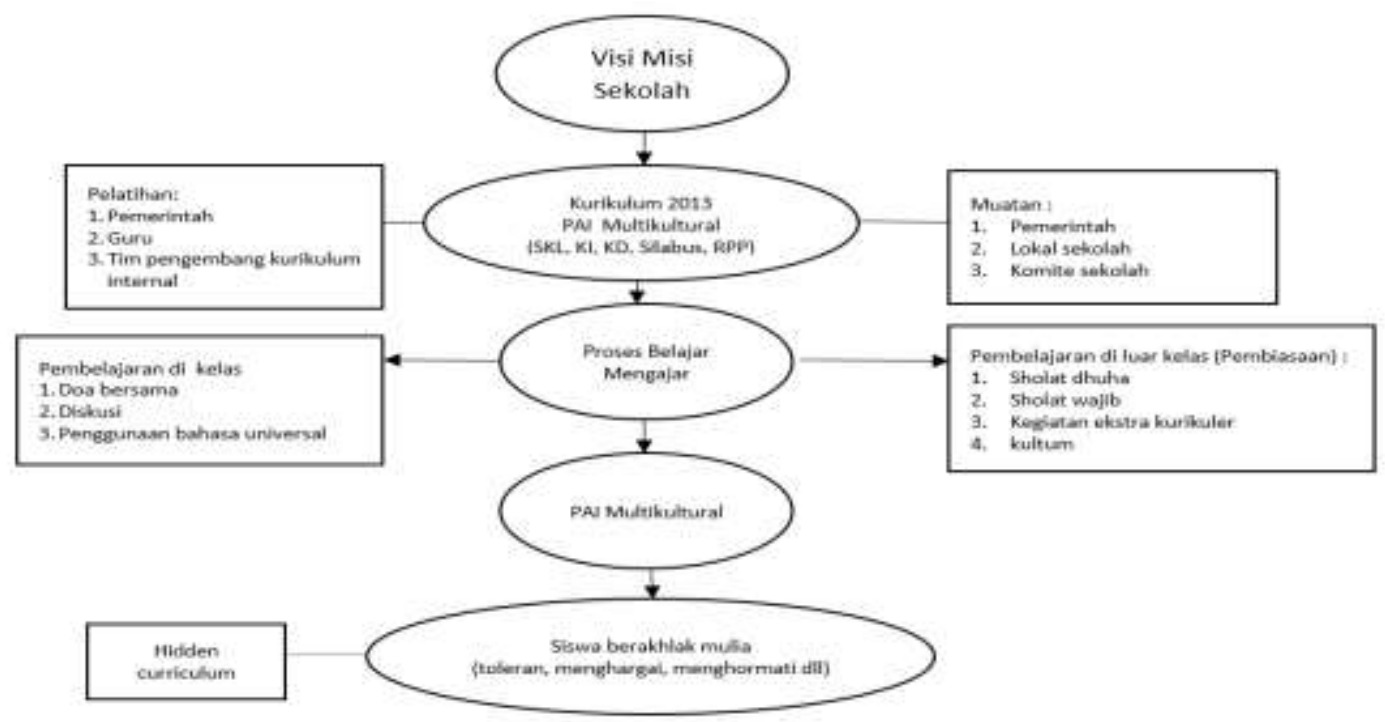

Gambar 1:

Model Pengembangan Kurikulum PAI Multikultural di SMA Kertajaya Surabaya

Pendidikan multikultural bermaksud mengakomidir tentang arti penting latar belakang peserta didik, baik ditinjau dari aspek budaya, etnis, dan agamanya, untuk selanjutnya disikapi dengan penuh toleran dan semangat egaliter. ${ }^{29}$ Hal ini dilakukan karena banyak kita jumpai di sekolah-sekolah umum di dalam satu kelas saja terdiri dari berbagai siswa yang sangat beragam sekali, ada yang berbeda agama, etnis, bahasa, suku, dan lain sebagainya.

Begitu juga halnya apa yang ada di SMA Kertajaya Surabaya. Peserta didik yang bersekolah disana beragam, dari segi budaya, suku, agama dan strata sosial, meskipun sekolah tersebut dibawah naungan yayasan yang berdasar pada Agama Islam. Namun siswa yang beragam tersebut dapat hidup berdampingan di sekolah dengan rukun dan guyub.

Pembelajaran Pendidikan Agama Islam yang dilaksanakan di SMA Kertajaya Surabaya merujuk pada teori yang dikembangkan oleh Tilaar, yakni mengacu pada lima dimensi pendidikan multikultur yang juga merujuk kepada konsep James A.

\footnotetext{
${ }^{29}$ Choirul Mahfud, Pendidikan Multikultural (Yogyakarta: Pustaka Pelajar, 2016), 176.
} 
Banks yaitu adanya integrasi pendidikan dalam kurikulum (content integration). Adanya integrasi materi pembelajaran mencakup keluasan bagi guru dalam memberikan contoh-contoh, data, dan informasi dari berbagai kebudayaan dan kelompok untuk mengilustrasikan konsep-konsep kunci, prinsip-prinsip, generalisasi, dan teori-teori dalam bidang atau displin ilmunya. Sumber rujukan untuk content integration mencakup pada apa yang seharusnya dimasukkan ke dalam kurikulum dan harus ditempatkan di mana dalam kurikulum tersebut. Adapun yang dipertimbangkan adalah siapa yang harus mengikuti materi pembelajaran etnik, baik itu sebagian peserta didik ataupun keseluruhan peserta didik dan relevansinya dengan dengan materi pembelajaran. ${ }^{30}$ Artinya SMA Kertajaya Surabaya menggunakan kurikulum 2013 dan berusaha mengintergrasikan kurikulum tersebut dengan memasukkan pendidikan multikultural, meskipun dengan cara dan gaya sekolah sendiri. Kondisi eksternal akan disesuaikan dengan kebutuhan internal melalui penyesuaian-penyesuaian. ${ }^{31}$

Terkait kurikulum, kurikulum PAI yang diterapkan oleh SMA Kertajaya Surabaya tetap mengacu pada kurikulum 2013, karena sekolah menganggap kurikulum 2013 sudah mencantumkan nilai-nilai multikultural dalam cakupan materinya. Meskipun demikian guru PAI berusaha menghubungkan materi-materi lain dengan mencantumkan nilai-nilai multikultural di dalamnya. Misalnya di kelas XI ada materi tentang toleransi, maka guru akan memberikan pengetahuan tentang perbedaan agama, ataupun dasar perbedaan ritual dalam golongan agama dan memberikan mereka pengertian tentang sikap saling menghargai dengan perbedaan tersebut. Hal ini menjadi penting karena peserta didik tidak hanya dibekali pengetahuan atau pemahaman tunggal namun juga diberikan pengetahuan tentang mengapa bisa berbeda yang bisa didapat salah satunya melalui pengalaman. ${ }^{32}$ Peserta didik tidak hanya cukup untuk menguasai landasan teori mengenai suatu topik, tetapi juga penting mendapatkan pengalaman praktik yang intensif. Artinya guru penting untuk mengelola proses pembelajaran dengan memasukkan pengalaman langsung

\footnotetext{
${ }^{30}$ H.A.R. Tilaar, Kekuasaan Dan Pendidikan (Magelang: Indonesia Tera, 2003), 211.

31 Triana Rosalina Noor, "Analisis Desain Fasilitas Umum Bagi Penyandang Disabilitas (Sebuah Analisis Psikologi Lingkungan),” Journal An-Nafs: Kajian Penelitian Psikologi 2, no. 2 (2017): 138.

32 Askhabul Kirom, "Peran Guru Dan Peserta Didik Dalam Proses Pembelajaran Berbasis Multikultural," Al Murabbi 3, no. 1 (2017): 71.
} 
didalamnya. ${ }^{33}$ Selain itu keteladanan guru dalam bersikap juga menjadi faktor pendukung keberhasilan proses pembelajaran. ${ }^{34}$

Dalam pengembangan kurikulum Pendidikan Agama Islam di SMA Kertajaya terlebih dahulu melakukan peninjauan ulang atau evaluasi terhadap kurikulumkurikulum yang telah berlaku sebelumnya. Peninjauan ulang tersebut dilakukan untuk mengetahui kekurangan-kekurangan dari kurikulum sebelumnya sehingga dengan begitu diharapkan hasil peninjauan tersebut dapat mendiagnosa kebutuhankebutuhan peserta didik. Pengembangan kurikulum PAI berbasis multikultural di SMA Kertajaya ini juga cenderung bersifat top down dan bottom up. Dikatakan termasuk model pengembangan kurikulum yang bersifat top down karena pengembangan kurikulum PAI tersebut tetap terpacu pada kebijakan pemerintah untuk mengaplikasikan kurikulum 2013, namun pengembangan kurikulum yang bersifat bottom up merupakan pengembangan yang dilakukan oleh internal pengembang SMA Kertajaya.

Sebagaimana Peter E. Oliva bahwa model perkembangan kurikulum, ada yang model deduktif dan model induktif.. Model deduktif adalah model yang dimulai dari hal umum ke hal khusus. Model induktif adalah model yang dimulai dari hal khusus ke hal umum. Tiga model deduktif yang disajikan adalah model Tyler; model Saylor, Alexander, Lewis; dan model Oliva. Untuk model induktif yang disajikan adalah model Taba. ${ }^{35}$

Terkait model pengembangan kurikulum yang diterapkan di SMA Kertajaya hampir mirip dengan model yang dikemukakan oleh Saylor, Alexander dan Lewis. Model ini menunjukkan bahwa perencana kurikulum mulai dengan menentukan atau menetapkan tujuan sasaran pendidikan yang khusus dan utama yang akan mereka capai. Tujuan sasaran pendidikan yang khusus dan utama akan ditujukan ke dalam empat bidang kegiatan dimana pembelajaran terjadi, yaitu : perkembangan pribadi, kompetensi social, ketrampilan yang berkelanjutan dan spesialisasi. Setelah tujuan dan

\footnotetext{
33 Iif Khoiru Ahmadi and Sofan Amri, Pengembangan \& Model Pembelajaran Tematik Integratif (Jakarta: PT. Prestasi Pustakaraya, 2014), 141.

34 Triana Rosalina Noor, "Upaya Guru Dalam Menanamkan Nilai Agama Di KB Al Muslim Surabaya," EDUSLANA: Jurnal Manajemen dan Pendidikan Islam 4, no. 1 (2017): 66.

35 Peter F. Oliva, Developing The Curriculum 3rd Edition (New York: Harper Collins Publisher, 1992), 159.
} 
sasaran serta bidang kegiatan ditetapkan, perencana memulai proses merancang kurikulum dan guru-guru yang menjadi bagian dari rencana kurikulum, harus membuat rencana pengajaran. Mereka memilih metode bagaimana kurikulum dapat dihubungkan dengan peserta didik. Guru pada tahap ini harus dikenalkan dengan istilah tujuan pengajaran sehingga guru dapat memerinci tujuan pengajaran sebelum memilih strategi atau cara presentasi. Setelah itu dilakukan evaluasi memungkinkan perencana kurikulum menetapkan apakah tujuan sekolah dan tujuan pengajaran telah tercapai. ${ }^{36}$

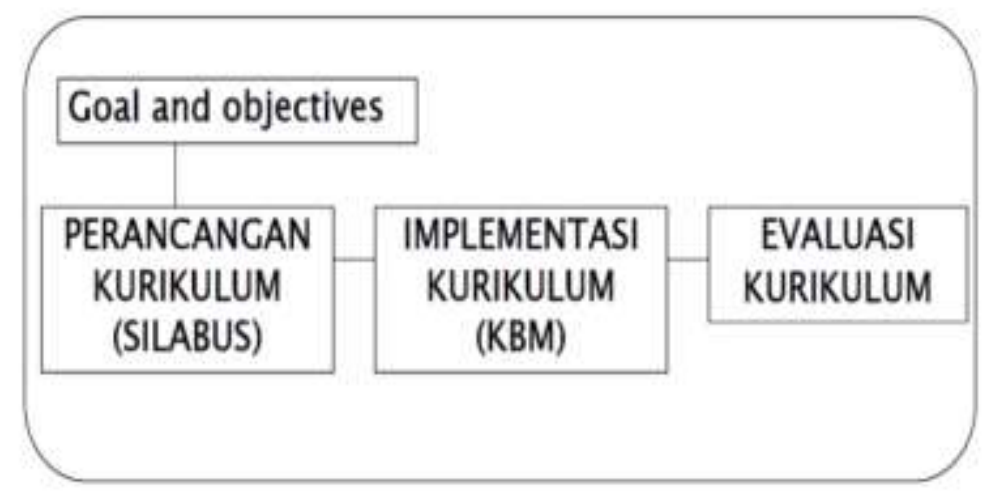

Gambar 2 : Model Pengembangan Kurikulum Saylor, Alexander dan Lewis

\section{KESIMPULAN}

Pengembangan kurikulum agar dapat berhasil sesuai dengan yang diinginkan, maka dalam pengembangan kurikulum diperlukan landasan-landasan pengembangan kurikulum. landasan pengembangan kurikulum mencakup: landasan filosofis, landasan sosial, psikologis, teoritik dan sosiologis.

Prinsip umum pengembangan kurikulum, khususnya kurikulum PAI di SMA Kertajaya mempertimbangkan relevansi, fleksibilitas, kontinuitas, praktis, dan efektivitas. PAI multikultural yang diterapkan bersifat dinamis, selalu berubah, menyesuaikan diri dengan kebutuhan siswa. Perumusan kurikulum PAI berbasis multiultural didasarkan pada analisis situasi yang dihadapi masyarakat, termasuk

\footnotetext{
${ }^{36}$ Ibid., 163-164.
} 
situasi lingkungan belajar dalam arti menyeluruh, situasi siswa, dan para pengajar yang diharapkan melaksanakan kegiatan.

Strategi yang lebih baik lagi dalam pengembangan ini ialah kebersamaan para guru dan siswa dan unsur terkait untuk mengevaluasi kurikulum dan pembelajaran yang sudah ditempuh, khususnya pada pembelajaran PAI dengan memasukkan nilainilai multikultural didalamnya. Nilai-nilai ini tercermin dari rasa keadilan, kasih, dan sayang, saling menghargai baik antara para guru dan siswa, antara institusi sekolah dan para unsur didalam sekolah serta antara manusia satu dan manusia satunya di dalam masyarakat

\section{DAFTAR PUSAKA}

Ahmadi, Iif Khoiru, and Sofan Amri. Pengembangan \& Model Pembelajaran Tematik Integratif. Jakarta: PT. Prestasi Pustakaraya, 2014.

Arifin, Zainal. Konsep Dan Model Pengembangan Kurikulum. Bandung: PT. Remaja Rosdakarya, 2012.

Baidhawy, Zakiyuddin. Pendidikan Agama Berwawasan Multikultural. Jakarta: Erlangga, 2007.

Ghony, M. Djunadi, and Fauzan Almanshur. Metodologi Penelitian Kualitatif. Yogyakarta: Ar-Ruzz Media, 2017.

Gunawan, Heri. Kurikulum Dan Pembelajaran Pendidikan Agama Islam. Bandung: CV. Alfabeta, 2012.

Harto, Kasinyo. Model Pengembangan Pendidikan Agama Islam Berbasis Multikultural. Jakarta: PT. RajaGrafindo Persada, 2014.

Hidayat, Ahmad Wahyu. "Studi Kebijakan Pengembangan Kurikulum Pendidikan Agama Islam Model Kurikulum 2013.” AL-MURABBI: Jurnal Studi Kependidikan dan Keislaman 6, no. 2 (2020): 172-188.

Kirom, Askhabul. "Peran Guru Dan Peserta Didik Dalam Proses Pembelajaran Berbasis Multikultural." Al Murabbi 3, no. 1 (2017): 69-80.

Mahfud, Choirul. Pendidikan Multikultural. Yogyakarta: Pustaka Pelajar, 2016.

Noor, Triana Rosalina. "Alternatif Pemecahan Masalah Pada Masyarakat Multikultural." Al Iman: Jurnal Keislaman dan Kemasyarakatan 4, no. 2 (2020): 204 232.

. "Analisis Desain Fasilitas Umum Bagi Penyandang Disabilitas (Sebuah Analisis Psikologi Lingkungan)." Journal An-Nafs: Kajian Penelitian Psikologi 2, no. 2 (2017): 133-150.

—. "Manajemen Pendidikan Anak Melalui Program Outbound Di TK Al 
Muslim Surabaya.” SELING: Jurnal Program Studi PGRA 3, no. 2 (2017): 64-75.

"Menepis Prasangka Dan Diskriminasi Dalam Perilaku Beragama Untuk Masa Depan Multikulturalisme Di Indonesia." Fikri: Jurnal Kajian Agama, Sosial dan Budaya 5, no. 2 (2020): 210-222.

"Meneropong Indonesia: Sebuah Analisis Sosiologis Dan Psikologis Atas Konflik Benuansa Keagamaan Di Indonesia." Journal An-Nafs: Kajian Penelitian Psikologi 3, no. 2 (2018): 135-150.

- "MENGEMBANGKAN JIWA KEAGAMAAN ANAK (Perspektif Pendidikan Islam Dan Perkembangan Anak Usia Dini)." KUTTAB 4, no. 2 (2020).

—. "Pendidikan Islam Sebagai Sebuah Sistem Di Era 4.0." TA'LIM: Jurnal Studi Pendidikan Islam 2, no. 2 (2019): 18-36.

_. "Remaja Dan Pemahaman Agama." Vicratina: Jurnal Pendidikan Islam 3, no. 2 (2019): 54-70.

-. "Upaya Guru Dalam Menanamkan Nilai Agama Di KB Al Muslim Surabaya." EDUSLANA: Jurnal Manajemen dan Pendidikan Islam 4, no. 1 (2017): 65-82.

Oliva, Peter F. Developing The Curriculum 3rd Edition. New York: Harper Collins Publisher, 1992.

Poerwati, Loeloek Endah, and Sofan Amri. Panduan Memahami Kurikulum 2013: Sebuah Inovasi Struktur Kurikulum Penunjang Pendidikan Masa Depan. Jakarta: PT. Prestasi Pustakaraya, 2013.

Sugiyono, Sugiyono. Metode Penelitan Pendidikan: Pendekatan Kuantitatif, Kualitatif Dan R\&D. Bandung: CV. Alfabeta, 2016.

Suparta, Suparta. Pengantar Teori Dan Aplikasi Pengembangan Kurikulum PAI. Jakarta: PT. RajaGrafindo Persada, 2016.

Tilaar, H.A.R. Kekuasaan Dan Pendidikan. Magelang: Indonesia Tera, 2003.

Widyastono, Herry. Pengembangan Kurikulum Di Era Otonomi Daerah Dari Kurikulum 2004, 2006 Ke Kurikulum 2013. Jakarta: CV. Bumi Aksara, 2015.

"No Title." http://repositori.kemdikbud.go.id/4265/1/01-a-salinan-permendikbudno-54-tahun-2013-ttg-skl.pdf. 